\title{
Ekspresi Glukosa Transporter-2 di Sel Beta Pankreas dan Sel Hepatosit Tikus yang Diinduksi Diabetes Mellitus
}

\author{
Teodhora $^{1 *}$, Depi Yuliana ${ }^{2}$, Ficanata Adhiguna Toding ${ }^{3}$ \\ ${ }^{1}$ Farmasi, Fakultas Farmasi, Institut Sains dan Teknologi Nasional, Jakarta Selatan, Indonesia \\ ${ }^{2}$ Farmasi, Fakultas Kesehatan, Universitas Qamarul Huda Badaruddin, Nusa Tenggara Barat, Indonesia \\ ${ }^{3}$ Farmasi, Fakultas Farmasi, Akademi Farmasi Tadulako Farma, Sulawesi Tengah, Indonesia
}

\begin{tabular}{l} 
INFO ARTIKEL \\
\hline Sejarah artikel: \\
Penerimaan \\
naskah: 17 Januari \\
2021 \\
Penerimaan \\
naskah revisi: 1 \\
Februari 2021 \\
Disetujui untuk \\
dipublikasikan: 29 \\
Mei 2021 \\
Kata kunci : \\
Ekspresi protein \\
GLUT-2, Sel $\quad \beta$ \\
pancreas, $\quad$ Sel \\
Hepatosit
\end{tabular}

\section{A B S T R A K}

Diabetes Mellitus (DM) merupakan penyakit yang tidak dapat disembuhkan namun dapat dicegah pemburukkan klinisnya. Penyakit ini berdasarkan klasifikasinya berhubungan dengan kerusakan pankreas secara total maupun parsial sehingga berdampak pada produksi insulin. Glukosa transporter merupakan suatu protein yang dapat mengangkut glukosa dari luar sel masuk ke dalam sel dan memberikan peran penting homeostatis glukosa tubuh. Glukosa transporter-2 (GLUT-2) terdapat pada pankreas, hati dan ginjal. Parameter yang digunakan adalah ekspresi dan jumlah densitas GLUT-2 di sel $\beta$ pankreas dan di sel hepatosit terhadap tikus normal dan tikus yang diinduksi diabetes. Digunakan tikus putih jantan galur Wistar. Teknik pewarnaan imunohistokimia (IHC) dilakukan untuk mengamati ekspresi GLUT-2 dan program macbiophotonics image $J$ untuk mengetahui densitas GLUT-2. GLUT-2 ditandai dengan warna coklat pada inti sel yang dikelilingi sitoplasma. Diperoleh hasil terjadi peningkatan ekspresi GLUT-2 di sel hepatosit dengan jumlah densitas 25.447.052 dan penurunan ekspresi GLUT-2 di sel $\beta$ pankreas dengan jumlah densitas 5.074.544 pada tikus DM yang diinduksi Streptozotosin $50 \mathrm{mg} / \mathrm{kg}$ BB-Nikotinamid 100 $\mathrm{mg} / \mathrm{kg}$ BB melalui rute Intraperitonial (STZ-NA). Induksi STZ-NA memicu kerusakan di sel $\beta$ pankreas dan berpengaruh terhadap ekspresi protein GLUT-2. Kadar glukosa darah yang tinggi memberikan aktivitas jumlah GLUT-2 yang berbeda pada sel hepatosit akibat efek dari agen penginduksi.

\section{Expression of Glucose Transporter-2 in Pancreas Beta Cells and Hepatocyte Cells Rat Induced by Diabetes Mellitus}

\section{Keywords:}

GLUT-2 protein

expression,

pancreatic $\beta$ cells,

Hepatocyte cells

\section{A BSTRACT}

Diabetes Mellitus (DM) is an incurable condition that is clinically curable from becoming worse. This disease is based on a class related to absolute or partial pancreatic damage affecting insulin production. The glucose transporter is a membrane that can transport glucose from the outside cell into a cell and plays an important feature in the homeostasis of glucose in the body. The pancreas, liver, and kidney produce glucose transporter-2 (GLUT-2). The expression and the total amount of GLUT-2 density in pancreatic $\beta$-cells and hepatocyte cells in normal and diabetic rats are the parameters used. They used white male rats of the Wistar strain. To measure the density of GLUT-2, the immunohistochemistry (IHC) staining technique was performed to investigate the expression of GLUT-2 and the macbiophotonic image J program. In a cell nucleus surrounded by cytoplasm, GLUT-2 is marked in brown. Results showed an increased expression of GLUT-2 in hepatocyte cells with a total density of 25,447,052 and a decreased expression of GLUT-2 in pancreatic $\beta$ cells with a total density of $5,074,544$ Streptozotocin $50 \mathrm{mg} / \mathrm{kg}$ BB-Nicotinamide $100 \mathrm{mg} / \mathrm{kg}$ BB (STZ-NA) Intraperitoneal routes in induced DM rats. STZ-NA induced damage in pancreatic $\beta$-cells and influenced GLUT-2 protein expression. High blood glucose levels give hepatocyte cells different GLUT-2 activity due to the effects of an induced agent. 


\section{Pendahuluan}

Kebutuhan glukosa pada setiap individu berbedabeda tergantung berat atau ringannya aktivitas yang dilakukan sehari-hari karena berpengaruh terhadap kebutuhan energi. Normalnya, pankreas akan menangkap sinyal kehadiran glukosa dengan memicu produksi dan pelepasan hormon insulin dari pulau Langerhans yaitu sel $\beta$ pankreas. Hormon ini akan berikatan dengan sisi reseptornya yang paling aktif, kemudian glukosa di dalam darah akan masuk ke dalam sel dan diubah menjadi energi sesuai dengan kebutuhan tubuh, jika kebutuhan telah tercukupi maka kelebihan glukosa akan disimpan dalam bentuk glikogen, kemudian akan diubah untuk digunakan kembali sesuai dengan asupan kebutuhan energi tubuh.

Mengkonsumsi $75 \mathrm{~g}$ glukosa dapat menyebabkan kadar insulin plasma meningkat dari 20-30 pmol/L menjadi 250-300 pmol/L dalam 30 menit sedangkan mengkonsumsi lemak atau protein ditambah diet lemak dalam jumlah yang sama akan meningkatkan kadar insulin plasma 50-60 pmol/L pada manusia. ${ }^{1}$ Glukosa membutuhkan kendaraan untuk berpindah dari luar sel ke dalam sel, kendaraan tersebut dikenal sebagai Glukosa Transporter yang tersebar luas di dalam tubuh di antaranya Glukosa Transporter-2 (GLUT-2) yang terdapat di pankreas dan hati. Sebaliknya, pada kondisi Diabetes Mellitus (DM) siklus tersebut diketahui terganggu.

DM dikenal sebagai penyakit dengan gangguan metabolisme yaitu terjadinya hiperglikemia karena kekurangan insulin atau gangguan efektivitas kerja insulin yang terjadi akibat pola hidup atau genetik. ${ }^{2}$ DM merupakan suatu penyakit yang dapat terjadi pada semua kalangan masyarakat, dikarenakan tingginya kadar glukosa secara terus-menerus di dalam darah. Hal ini dapat terjadi karena berbagai penyebab di antaranya kebiasaan sering mengkonsumsi makanan yang terlampau manis, kurangnya aktivitas fisik, faktor keturunan, gangguan hormonal, ketidakpahaman masyarakat karena secara bebas menggunakan beberapa obat-obatan yang jangka panjang beresiko memicu penyakit diabetes mellitus. DM dikenal sebagai penyakit degeneratif yang tidak dapat disembuhkan namun perkembangan klinisnya dapat dicegah sehingga tidak memberikan dampak komplikasi terhadap organ tubuh lainnya.

Streptozotosin (STZ) adalah senyawa glukosamin yang memiliki efek toksik karena kerjanya selektif di sel $\beta$ pankreas dan berperan dalam menginduksi DM melalui peran GLUT-2, sehingga tubuh akan mengalami metabolisme dan akan menghasilkan nitrit oksida. Namun, kehadiran nikotinamid (NA) dapat meringankan toksisitas STZ dan dapat mencegah penipisan di sel $\beta$ pankreas. ${ }^{3,4}$ STZ bersifat hidrofilik, dimana zat ini membatasi secara bebas difusi karena hidrofobisitasnya pada membran sel plasma yang terdiri dari fosfolipid bilayer. ${ }^{5}$ Tingginya kadar glukosa di dalam darah berpotensi menyebabkan terjadinya kerusakan pada pankreas dan hati yang dipengaruhi oleh transporter glukosa. Adapun maksud dan tujuan penelitian ini adalah untuk melihat ekspresi peningkatan dan penurunan densitas jumlah GLUT-2 di sel $\beta$ pankreas dan di sel hepatosit tikus putih jantan yang dibuat DM melalui induksi STZ-NA.

\section{Metode}

\subsection{Alat dan Bahan}

Alat yang digunakan yaitu rotary mikrotom (VIC), preparat sel (sail brand). Bahan yang digunakan yaitu, anti GLUT-2 (1:100), enzim peroksida, diaminobenzinin (DAB), counterstain (1 celupan), streptozotosin (Sigma Aldrich, $50 \mathrm{mg} / \mathrm{kgBB}$ ), nikotinamid (Merck, 110 $\mathrm{mg} / \mathrm{kgBB})$, Na-CMC $1 \%$.

\subsection{Prosedur Kerja}

Kelompok perlakuan dibagi menjadi 2 kelompok yaitu kelompok kontrol normal dan kelompok kontrol negatif. Kontrol normal menggunakan sediaan suspensi Na-CMC $1 \%$ (rute P.O) sedangkan kontrol negatif menggunakan zat penginduksi yaitu nikotinamid $110 \mathrm{mg} / \mathrm{kg} \quad \mathrm{BB}-$ streptozotosin $50 \mathrm{mg} / \mathrm{kgBB}$ (rute I.P) dan sediaan suspensi Na-CMC $1 \%$ (rute P.O). Jumlah tikus (Rattus norvegicus) yang digunakan adalah 8 ekor dengan masing-masing kelompok adalah 2 ekor, yang kemudian digunakan untuk pengujian immunohistokimia pada organ pankreas dan organ hati.

Tikus (Rattus norvegicus) dianastesi dengan eter, dilanjutkan dengan kloral hidrat, lalu melalui abdomen dan toraks organ pankreas dan hati tikus diambil. Organ diambil dan dilakukan dihidrasi lalu dibersihkan dengan larutan xylem, kemudian diinfiltrasi. Penanaman jaringan dilakukan dan pemotongan blok preparat menggunakan mikrotom. Hasil potongan dari jaringan tersebut ditempel pada permukaan gelas obyek kemudian dilakukan deparafinasi menggunakan larutan xylol kemudian direhidrasi. Selanjutnya sampel jaringan dicuci menggunakan PBS dan ditetesi antibody anti GLUT-2. Tahap berikutnya adalah sampel jaringan diinkubasi kemudian dicuci menggunakan PBS, lalu ditetesi antibodi sekunder dan enzim peroksidasi lalu dicuci kembali dengan PBS. Sampel jaringan ditetesi DAB dan dicelupkan ke dalam counterstain, dicuci dengan air mengalir, kemudian dilakukan tahap dehidrasi kembali. Dilakukan pembersihan dan mounting kemudian mengamati hasil pewarnaan. Berdasarkan nomor surat 671/X/HREC/2015, penelitian ini telah mendapatkan izin kelayakan etik penelitian sebagai upaya melindungi hak asasi dan kesejahteraan dari penggunaan hewan uji.

\subsection{Analisis Data}

Analisis data semikuantitatif meliputi ekspresi protein GLUT-2 di sel $\beta$ pankreas dan sel hepatosit . Pemeriksaan ekspresi protein GLUT-2 dilakukan terhadap GLUT-2 dalam pankreas dan hepatosit tikus yang telah dilakukan pewarnaan secara imunohistokimia dengan perbesaran 130 dan 520 kali. Penentuan nilai luas dan intensitas protein GLUT-2 menggunakan bantuan program MacBiophotonics Image J. Data semikuantitatif yang diperoleh selanjutnya dilakukan perhitungan rata-rata untuk mendapatkan nilai dalam bentuk persentase. 


\section{Hasil dan Diskusi}

Hajiaghaalipour, 2015 melaporkan kehadiran glukosa memicu sekresi insulin melalui mediasi dari transporter glukosa di sel $\beta$ pankreas, hati dan sistem saraf yaitu hipotalamus. ${ }^{6}$ Glukosa merupakan sumber utama tubuh untuk memetabolisme energi dan digunakan pada sebagian besar sel, setelah makan kadar glukosa darah akan meningkat dimana glukosa akan diserap ke dalam otot atau jaringan adiposa sebagai respon terhadap insulin yang dikeluarkan dari sel $\beta$ pankreas dan digunakan sebagai energi. Namun, glukosa yang terus meningkat akan berdampak buruk pada fungsi sel $\beta$ pankreas dan kualitas hidup. $^{7}$

Sekresi insulin bergantung pada kadar glukosa darah, ATP-sensitive $K$ channels dan Voltage-sensitive Calcium Channels sel $\beta$ pankreas. Mekanisme kerjanya adalah pada keadaan puasa kadar glukosa akan menurun, maka ATP-sensitive $K$ channels di membran sel $\beta$ akan terbuka sehingga ion kalium akan meninggalkan sel $\beta$, dengan demikian mempertahankan potensial membran dalam keadaan hiperpolar sehingga kanal kalsium tertutup, akibatnya kalsium tidak dapat masuk ke dalam sel $\beta$ sehingga perangsangan sel $\beta$ untuk mensekresi insulin menurun. ${ }^{8,9}$ Sebaliknya pada keadaan setelah makan, kadar glukosa darah yang meningkat akan diangkut oleh sel $\beta$ melalui GLUT-2 dan dibawa ke dalam sel. Di dalam sel, glukosa akan mengalami fosforilase menjadi glukosa-6 fosfat (G6P) dengan bantuan enzim penting yaitu glukokinase. Glukosa 6 fosfat kemudian akan mengalami glikolisis dan akhirnya akan menjadi asam piruvat. Dalam proses glikolisis ini akan dihasilkan ATP. Penambahan ATP akan meningkatkan rasio ATP/ADP dan ini akan menutup pintu kanal kalium. Dengan demikian kalium akan tertumpuk dalam sel dan terjadi depolarisasi membran sel, sehingga membuka pintu kanal kalsium dan kalsium akan masuk ke dalam sel. Dengan meningkatnya kalsium intrasel, akan terjadi translokasi granul insulin ke membran dan insulin akan dilepaskan ke dalam darah. ${ }^{8,10}$

Parameter yang digunakan dalam penelitian ini adalah ekspresi dan jumlah GLUT-2 di sel $\beta$ pankreas dan di sel hepatosit. Hasil IHC pada tikus normal dan tikus yang diinduksi DM dapat dilihat pada Gambar 1 dan 2.

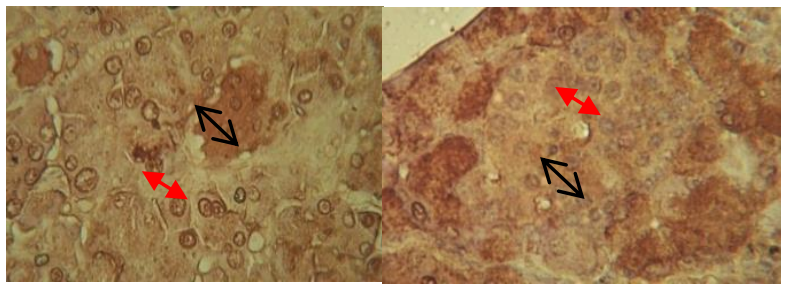

(a)

(b)

Gambar 1. (a) Ekspresi GLUT-2 sel $\beta$ tikus normal, (b). Ekspresi GLUT2 sel $\beta$ tikus DM pada perbesaran 520 kali. Panah hitam; GLUT-2 ditandai dengan warna cokelat, Panah merah; adanya inti sel yang dikelilingi sitoplasma berisi GLUT-2 di sel $\beta$ pankreas

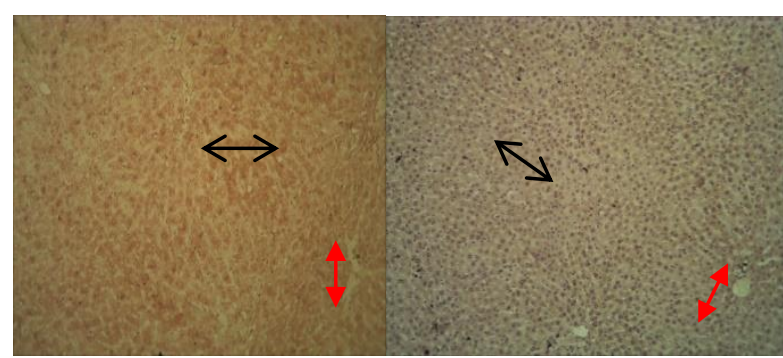

(a)

(b)

Gambar 2. (a) Ekspresi GLUT-2 sel hepatosit tikus normal, (b). Ekspresi GLUT-2 sel hepatosit tikus DM pada perbesaran 130 kali. Panah hitam; GLUT-2 ditandai dengan warna cokelat, Panah merah; adanya inti sel yang dikelilingi sitoplasma berisi GLUT-2 dan terdapat banyak celah rongga sinusoid di antara GLUT-2 di sel hepatosit.

Diperoleh persentase jumlah protein GLUT-2 yang berbeda akibat penginduksi STZ-NA, dilihat pada hasil IHC tikus normal, GLUT-2 di sel $\beta$ pankreas terjadi penurunan sebaliknya di sel hepatosit terjadi peningkatan GLUT-2. Hal ini mengindikasikan bahwa efek STZ mempengaruhi aktivitas GLUT-2. GLUT-2 bersifat afinitas rendah dengan kapasitas yang tinggi dalam penyerapan glukosa. Hal demikian diperjelas dengan warna dan jumlah GLUT-2 yang dihasilkan pada tikus diabetes signifikan berbeda dibandingkan tikus normal. Hasil densitas ekspresi protein GLUT-2 dapat dilihat pada Tabel 1.

Tabel 1.Hasil Densitas Ekspresi Protein GLUT-2 dari 8 Total Sampel denganPerbesaran $40 \mathrm{kali}$

\begin{tabular}{ccc}
\hline Pengamatan IHC & Organ Target & Densitas GLUT-2 \\
\hline Tikus Normal & Sel $\beta$ Pankreas & 15.703 .982 \\
Tikus Normal & Sel Hepatosit & 3.361 .319 \\
Tikus DM & Sel $\beta$ Pankreas & 5.704 .544 \\
Tikus DM & Sel Hepatosit & 25.447 .052 \\
\hline
\end{tabular}

GLUT-2 memiliki afinitas rendah terhadap glukosa seperti galaktosa, manosa, dan fruktosa, namun glukosamin memiliki afinitas yang sangat tinggi. GLUT-2 diduga terlibat dalam patogenesis diabetes mellitus, karena telah dibuktikan ekspresi GLUT-2 di proses dalam sel $\beta$ pankreas dan mengalami peningkatan ekspresi di hati pada hewan uji. ${ }^{6}$ GLUT-2 diekspresikan secara konstitusif dalam sel $\beta$ pankreas, glukosa memberikan keseimbangan dalam sel $\beta$ melalui penyerapan difusi terfasilitasi yang diperantarai oleh GLUT-2. Tingginya ekspresi GLUT-2 selain dalam sel $\beta$, juga diekspresikan dalam hati dan dalam kadar yang rendah di ginjal dan usus. ${ }^{1}$

GLUT-2 bukan hanya protein struktural namun juga secara signifikan sangat berperan dalam masuknya glukosa. GLUT-2 merupakan jalan glukosa untuk masuk ke dalam sel $\beta$ pankreas dan sebagai transporter glukosa utama pada tikus. GLUT-2 pada hati pertama kali terletak di basolateral (sinusoid) membran plasma yang berperan dalam homeostatis glukosa, dapat memanfaatkan bahkan memproduksi glukosa saat kondisi makan maupun berpuasa. Kadar glukosa darah yang tinggi memberikan aktivitas jumlah GLUT-2 yang berbeda pada sel hepatosit akibat efek dari penginduksi STZ.

Streptozotosin adalah suatu zat kimia yang dapat digunakan sebagai agen penginduksi DM tipe-1 dan DM 
tipe-2 tergantung dosis yang diberikan, namun dosis 40 $\mathrm{mg} / \mathrm{kg}$ BB kemungkinan tidaklah efektif. ${ }^{11}$ STZ dikaitkan dengan gangguan lipid yaitu peningkatan trigliserida, low density lipid, very low-density lipoprotein, dan penurunan high density lipid. Gangguan lipid akibat diabetes terjadi melalui mekanisme biokimia yaitu setelah induksi diabetes, maka aktivitas hormon lipase akan meningkat dan menyebabkan kerusakan trigliserida di jaringan adiposa yang disimpan dalam bentuk asam lemak kemudian dilepaskan ke sirkulasi sistemik. ${ }^{12}$

Kahraman, 2014 melaporkan STZ dalam menginduksi DM pada tikus dapat memberikan perubahan dalam struktur sel hepatosit dan fungsi hati serta penurunan penggunaan glukosa. Induksi STZ dapat meningkatkan stress oksidatif, menyebabkan disfungsi mitokondria, dan meningkatkan ekspresi GLUT-2 pada sel hepatosit tikus. Paparan dosis tinggi STZ memicu toksisitas yang lebih tinggi dan berbeda pada pankreas, hati, dan ginjal terhadap tingkat ekspresi GLUT-2. Konsentrasi glukosa darah yang tinggi akibat induksi STZ memberi dampak pada kegagalan fungsi sel $\beta$, sehingga memungkinkan memberi respon terjadi peningkatan ekspresi GLUT-2. Regulasi peningkatan GLUT-2, distimulasi oleh hadirnya glukosa di sel hepatosit secara langsung pada transkripsi gen. STZ pada dosis tinggi yang diberikan secara tunggal pada tikus dapat dengan cepat menghancurkan sel $\beta$ sehingga kadar glukosa menjadi sangat tinggi dan ekspresi GLUT-2 meningkat. ${ }^{13}$

Adapun penelitian sebelumnya mengenai GLUT-2 adalah penggunaan asam ferulik pada kondisi diabetes menunjukkan ekspresi GLUT-2 yang berlebih.Asam ferulik merupakan komponen fenolik yang dilaporkan dapat sebagai antidiabetes dan mengatur ekspresi GLUT-4 secara in vitro. Selain itu tikus yang diinduksi diet tinggi lemak dan fruktosa tinggi memberikan hasil peningkatan ekspresi GLUT-2 dalam jaringan hati pada hewan diabetes mellitus Tipe-2, dan penggunaan asam ferulik dapat mengurangi ekspresi GLUT-2 dengan cara menganggu interaksi antara faktor-faktor transkripsi dan promotor gen GLUT-2. ${ }^{14}$ Selain itu, dilaporkan hasil penelitian lainnya terjadi penurunan GLUT-2 yang signifikan pada pankreas dan terjadi peningkatan GLUT-2 yang signifikan pada hati dan paru-paru tikus yang diinduksi STZ. ${ }^{15}$

Hasil imunohistokimia GLUT-2 di sel $\beta$ pankreas dan sel hepatosit tikus yang diinduksi DM menggunakan STZ-NA menunjukkan hasil yaitu terjadi penurunan di sel $\beta$ pankreas dan peningkatan di sel hepatosit.Adapun manfaat dari penelitian ini adalah peningkatan glukosa di dalam tubuh secara terus menerus dapat memicu resiko terjadinya diabetes mellitus. Penyakit ini diketahui dapat memberikan pengaruh terhadap jumlah kendaraan yang mengangkut glukosa atau dikenal dengan transporter glukosa (GLUT-2) pada organ pankreas dan hati, yaitu pada pankreas akan menurun sedangkan di hati akan meningkat. Adapun saran untuk dilakukan penelitian lebih lanjut adalah menganalisis hubungan penurunan GLUT-2 di pankreas dan peningkatan GLUT-2 hati terhadap resiko terjadinya komplikasi makrovaskular atau mikrovaskular dengan waktu pengamatan lebih dari 14 hari.

\section{Daftar Pustaka}

1. Z Fu, Gilbert, D Liu. Regulation of Insulin Synthesis and Secretion and Pancreatic Beta-Cell Dysfunction in Diabetes. Curr Diabetes Rev. 2013. 1; 9(1):25-53.

2. World Health Organisation (WHO).Diabetes mellitus fact sheet; 2018. (Diakses online 24 April 2020).

3. TSzkudelski. Streptozotocinnicotinamide induced diabetes in the rat. Characteristics of the experimental model.Exp Biol Med (Maywood).2012. 237(5):48190.Doi:10.1258/ebm.2012.011372.

4. ATahara, A M. Yakono, R. Nakano, Y Someya, M Shibasaki. Hypoglycaemic Effects of Antidiabetic Drugs in Streptozotocin-Nicotinamide Induced Mildly Diabetic and Streptozotocin-Induced Severely Diabetic Rats.Basic Clin Pharmacol Toxicol.2008.103(6):560-8. Doi:10.1111/j.1742-7843.2008.00321.x.

5. C O Eleazu, K C Eleazu, S Chukwuma, U N Essien. Review of the mechanism of cell death resulting from streptozotocin challenge in experimental animals, its practical use and potential risk to humans. J Diabetes Metab Disord.2013. 12 (1):60. Doi:10.1186/22516581-12-60.

6. Hajiaghaalipour F,Khalilpourfarshbafi M, Arya A. Modulation of Glucose Transporter Protein by DietaryFlavonoids in Type 2 Diabetes Mellitus. International Journal of Biological Sciences.2015. 11(5): 508-524. Doi: 10.7150/ijbs.11241.

7. M Bensellam, DRLaybutt, JCJonas. 2012. The molecular mechanisms ofpancreatic beta-cell glucotoxicity: recent findings and future researchdirections. Mol Cell Endocrinol. 2012. 364(127). Doi: 10.1016/j.mce.2012.08.003.

8. Howell SL. The Biosynthesis and Secretion of Insulin. In :Text Book of Diabetes, Pickup JC, William G (eds), $2^{\text {nd }}$ ed. Blackwell Science Ltd. London 1997: pp 8.1-14.

9. White MF, Kahn RC. Molecular Aspect of Insulin Action. In Joslin's Diabetes Mellitus, 1994: pp.139-62.

10. Masharani U, Karam H J, German M S. Pancreatic Hormones \& Diabetes Mellitus. In Basic \& Clinical Endocrinology. $6^{\text {th }}$ ed. Greenspan FS, Gardner DG (eds), Mc Graw Hill, New York. 2001: pp. 623-48.

11. Gupta A, Sharma M, Sharma J. Review Article: A Role of Insulin in different types of Diabetes. Int.J.Curr.Microbiol.App.Sci. 2015. 4(1): 58-77. ISSN: 2319-7706.

12. Almeida D A, Braga CP, Novelli ELB, Fernandes A H. Evaluation of lipidprofile and oxidative stress in STZinduced rats treated with antioxidantvitamin. Brazilian Arch of Biology Technology. 2012. 55:4 (527-536). Doi :10.1590/S151689132012000400007.

13. S Kahraman, C Aydin, O G Elpek, E Dirice, D A Sanlioglu. Diabetes-Resistant NOR Mice Are More Severely Affected byStreptozotocin Compared to the Diabetes-Prone NOD Mice:Correlations with Liver and Kidney GLUT2 Expressions. J Diabetes Res. 2015. 450128. Doi:10.1155/2015/450128. 
14. A. Narasimhan, M. Chinnaiyan, B. Karundevi. Ferulic acid regulates hepatic GLUT2 gene expression in high fat and fructose-induced type-2 diabetic adult male rat.Eur J Pharmacol. 2015. 761(391-7). Doi:10.1016/j.ejphar.2015.04.043.

15. C Jurysta, C Nicaise, M H Giroix, S Cetik, WJ Malaisse, A Sener. Comparison of GLUT1, GLUT2, GLUT4 and SGLT1 mRNA Expression in the Salivary Glands and Six Other Organs of Control Streptozotocin-Induced and Goto-Kakizaki Diabetic Rats. Cell Physiol Biochem.2013. 31:1(37-43). Doi: $10.1159 / 000343347$. 